\title{
Contribution to research when engineering is taught through ODL: A Sri Lankan case study
}

\author{
Kolita S. Weerasekera \\ Open University of Sri Lanka, Sri Lanka
}

\begin{abstract}
This paper is based on a study that investigated a general conception that academics and students of engineering in ODL institutions conduct less research compared to those teaching and learning in conventional institutions of higher learning. The study first observed the level of research conducted by Sri Lankan researchers, and compared it to similar activities carried out in neighbouring countries. Subsequently, attention was focused on the Open University of Sri Lanka (OUSL), which is the pioneer ODL institution in Sri Lanka. It closely observed the research carried out at OUSL over the last few years and made comparisons between different disciplines.

A tracer study was carried out to identify the research activities at the Faculty of Engineering Technology over the years and compare them with the research done at other OUSL faculties. It was evident from this study that the number of research papers presented at conferences and journal articles generated by the Faculty of Engineering Technology was low compared to the number produced by the other three faculties in the university. The study revealed some interesting reasons for the low level of engineering-based research output when engineering is taught through $O D L$.
\end{abstract}

\section{Introduction}

The Faculty of Engineering Technology at the Open University of Sri Lanka (OUSL) has been teaching engineering courses using the Open and Distance Learning (ODL) mode over the last 25 years. The fields of engineering taught at OUSL are civil, computer, electrical, electronic and communication, mechatronics, and mechanical engineering. Although the faculty has produced about 400 graduates, the graduation rate has been low compared to that of the three conventional engineering faculties in the country.

OUSL launched an ODL engineering degree programme in 1980, at a time when this mode of delivery was not widely known. Even with current technological advancements in ODL, other institutions have yet to offer as wide a variety of engineering disciplines as OUSL does. Despite initial setbacks, the number of engineering graduates from OUSL has been increasing (Table 1). 


\begin{tabular}{|c|c|c|c|c|c|c|c|c|c|c|c|c|c|c|c|c|c|c|}
\hline Year & すั & ڤ̆ & ஜั & ลૂ & $\begin{array}{l}\infty \\
\text { ๙ }\end{array}$ & ু & ஓ̊ & ঠ্ণ & ్ํำ & ஜ̊ & ঠ্ঠি & ○̊ & ঠ̊ & 윰 & $\stackrel{\infty}{\circ}$ & 용 & $\stackrel{\circ}{\circ}$ & চ \\
\hline $\begin{array}{l}\text { Number of } \\
\text { Graduates }\end{array}$ & 19 & 13 & 12 & 08 & - & 10 & 12 & 19 & 12 & 23 & 17 & 26 & 29 & 31 & 28 & 71 & 64 & 58 \\
\hline
\end{tabular}

Table 1 The number of Bachelor of Engineering Technology graduates at OUSL (1994-2011)

Although graduate numbers have increased, the involvement of OUSL engineering faculty in disciplined-based research has not been comparable to such activities in the engineering faculties of conventional universities. This is evident from the number of research grants that have been granted, and the number of conference papers and journal articles that have been published annually by engineering faculty members of the various universities.

\section{Research and development}

Scientific research, innovation and creativity leading to technological advancements are hallmarks of economic development. This is historically evident from the rapid development of Europe, North America and Canada during the industrial revolution. It is also evident from Japan's economic growth after the Second World War, and the more recent growth of newly emerging economies such as China, Korea and India (Kulasooriya, 2011).

If we look at the research conducted in South and Southeast Asian countries, it can be seen that India tops the research publication list (Table 2). It is evident that India has emerged as a leading power in research and development, paving the way for a giant economy in the region. It also can be seen that the number of research publications in Sri Lanka has not been satisfactory; it was only ahead of Nepal from 2005 to 2009. The reason for this low level of research output is that the expenditure for research in Sri Lanka is lower than that of neighbouring countries.

\begin{tabular}{|l|r|r|r|r|r|}
\hline \multicolumn{1}{|c|}{ Country } & \multicolumn{1}{c|}{$\mathbf{2 0 0 5}$} & \multicolumn{1}{c|}{$\mathbf{2 0 0 6}$} & \multicolumn{1}{c|}{$\mathbf{2 0 0 7}$} & \multicolumn{1}{c|}{$\mathbf{2 0 0 8}$} & \multicolumn{1}{c|}{$\mathbf{2 0 0 9}$} \\
\hline India & 19,448 & 20,705 & 22,215 & 25,377 & 25,647 \\
\hline Singapore & 5,316 & 5,438 & 5,407 & 6,257 & 6,543 \\
\hline Thailand & 2,270 & 2,552 & 2,940 & 3,466 & 3,630 \\
\hline Pakistan & 769 & 877 & 1,110 & 1,505 & 1,591 \\
\hline Malaysia & 518 & 535 & 661 & 698 & 752 \\
\hline Bangladesh & 407 & 455 & 464 & 542 & 558 \\
\hline Sri Lanka & 242 & 241 & 269 & 303 & 300 \\
\hline Nepal & 142 & 183 & 166 & 145 & 170 \\
\hline
\end{tabular}

Table $2 \mathrm{SCl}$ publications over five years Source: Science Citation Index: The Thomson Corporation 
The gross expenditure on research and development (GERD) as a percentage of gross domestic product (GDP) was $0.11 \%$ in Sri Lanka. In India, it was $0.8 \%$, on top of the huge difference in the GDPs of the two countries. In Sri Lanka, the GERD for 2008 was US $\$ 46.1$ million whereas in India it was US $\$ 2,263$ million, which is about 50 times the Sri Lankan figure (UNESCO Statistics, 2009). This probably explains the low number of research publications in Sri Lanka compared to India.

Let us look at the number of Sri Lankan researchers involved in conducting and publishing research. Table 3 indicates the number of research and development scientists and technicians employed by different sectors from 2006 to 2008. It shows that about $60 \%$ of the research scientists and $40 \%$ of the research technicians in the country are from the universities. This shows the heavy involvement of Sri Lankan universities in research and development.

\begin{tabular}{|c|c|c|c|c|c|c|c|c|c|}
\hline & \multirow{3}{*}{ Sector } & \multicolumn{4}{|c|}{2006} & \multicolumn{4}{|c|}{2008} \\
\hline & & \multicolumn{2}{|c|}{ Scientists } & \multicolumn{2}{|c|}{ Technicians } & \multicolumn{2}{|c|}{ Scientists } & \multicolumn{2}{|c|}{ Technicians } \\
\hline & & No: & $\%$ & No: & $\%$ & No: & $\%$ & No: & $\%$ \\
\hline (1) & $\begin{array}{l}\text { Universities } \\
\text { and Higher } \\
\text { Education } \\
\text { Institutions }\end{array}$ & 2,839 & $62.8 \%$ & 807 & $42.1 \%$ & 2,466 & $61.1 \%$ & 793 & $36.6 \%$ \\
\hline (2) & State Sector & 1,479 & $32.9 \%$ & 1,031 & $53.7 \%$ & 1,187 & $29.4 \%$ & 1,204 & $55.6 \%$ \\
\hline (3) & $\begin{array}{l}\text { Private Sector } \\
\text { and NGO }\end{array}$ & 202 & $4.5 \%$ & 80 & $4.2 \%$ & 384 & $9.5 \%$ & 169 & $7.8 \%$ \\
\hline Tot & & 4,520 & $100 \%$ & 1,918 & $100 \%$ & 4,037 & $100 \%$ & 2,166 & $100 \%$ \\
\hline
\end{tabular}

Table 3 Number of research and development scientists/technicians by sector in Sri Lanka Source: National R \& D Surveys, Sri Lanka 2006 and 2008, NSF

\section{Research and development at ODL institutions}

As cited by Braimoh (2002), despite the glowing virtues of distance education, the common perception is that this process of teaching and learning is an inferior mode of educational acquisition; one that has less research and innovation. However, a tracer study of students graduating from OUSL in 2009 showed that more than $80 \%$ of the engineering graduates were fully satisfied with their laboratory experience and field exposure while going through the undergraduate programme at the university (Gunawardena and Ekanayake, 2010). According to Lephoto (2000), distance education has great potential because it can provide more than what the formal system can provide. Hence, the development and sustainability of ODL institutions are increasing. 
Contribution to research when engineering is taught through ODL:

A Sri Lankan case study

Distance learning institutions are perceived to be conducting less discipline-based research compared to conventional universities which have more face-to-face interaction with students. This perception is commonly applied to all science disciplines, especially engineering. As mentioned earlier, the Faculty of Engineering Technology at OUSL is one of the very few institutions in the world which teaches core engineering programmes through ODL. Although the faculty faced some difficulties in the initial stages of the engineering programmes, it has come a long way in improving the number and quality of students graduating annually

(Table 1).

The number of conference papers and journal articles produced by staff and students of the faculty is fewer compared to the number produced by the engineering faculties in conventional universities. OUSL has four faculties, namely the Faculty of Engineering Technology, the Faculty of Natural Sciences, the Faculty of Humanities and Social Sciences, and the Faculty of Education. From 2005 to 2010, OUSL organised five research conferences in which the academics and students from the four faculties participated. The number of presentations made by the academic staff members and students from the different faculties is listed in Table 4. When the four faculties are compared, it can be seen that the Faculty of Engineering Technology produced the lowest number of conference papers and journal articles.

\begin{tabular}{|c|c|c|c|c|c|c|c|c|}
\hline & \multicolumn{3}{|c|}{$\begin{array}{l}\text { Faculty of Engineering } \\
\text { Technology }\end{array}$} & \multirow{2}{*}{ 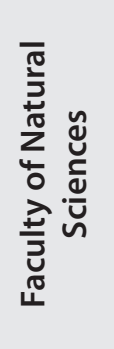 } & \multirow{2}{*}{ 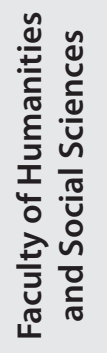 } & \multirow{2}{*}{ 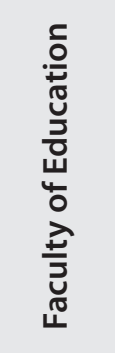 } & \multirow{2}{*}{$\begin{array}{l}\vec{n} \\
\stackrel{0}{0} \\
\frac{0}{0} \\
\frac{0}{n} \\
\frac{5}{0}\end{array}$} & \multirow{2}{*}{ 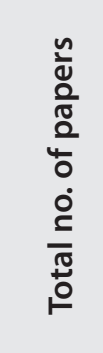 } \\
\hline & Engi & Agri & Text & & & & & \\
\hline $\begin{array}{l}25^{\text {th }} \\
\text { Anniversary } \\
\text { Conference } \\
2005\end{array}$ & 00 & 00 & 02 & 06 & 07 & 08 & - & 23 \\
\hline Percentage (\%) & $0 \%$ & $0 \%$ & $8.7 \%$ & $26.1 \%$ & $30.4 \%$ & $34.8 \%$ & - & $100 \%$ \\
\hline $\begin{array}{l}\text { Academic } \\
\text { Sessions } 2007\end{array}$ & 00 & 05 & 01 & 16 & 09 & 02 & - & 33 \\
\hline Percentage (\%) & $0 \%$ & $15 \%$ & $3.1 \%$ & $48.5 \%$ & $27.3 \%$ & $6.1 \%$ & - & $100 \%$ \\
\hline $\begin{array}{l}\text { Academic } \\
\text { Sessions } 2008\end{array}$ & 02 & 08 & 03 & 12 & 10 & 05 & - & 40 \\
\hline Percentage (\%) & $5 \%$ & $20 \%$ & $7.5 \%$ & $30 \%$ & $25 \%$ & $12.5 \%$ & - & $100 \%$ \\
\hline $\begin{array}{l}\text { Academic } \\
\text { Sessions } 2009\end{array}$ & 07 & 08 & 06 & 18 & 12 & 07 & - & 58 \\
\hline Percentage (\%) & $12 \%$ & $14 \%$ & $10.2 \%$ & $31 \%$ & $20.7 \%$ & $12.1 \%$ & - & $100 \%$ \\
\hline
\end{tabular}




\begin{tabular}{|c|c|c|c|c|c|c|c|c|}
\hline $\begin{array}{l}30^{\text {th }} \\
\text { Anniversary } \\
\text { Conference } \\
2010\end{array}$ & 03 & 00 & 00 & 04 & 05 & 10 & 17 & 39 \\
\hline Percentage (\%) & $7.7 \%$ & $0 \%$ & $0 \%$ & $10.3 \%$ & $12.8 \%$ & $25.6 \%$ & $43.6 \%$ & $100 \%$ \\
\hline Total & $\begin{array}{c}12 \\
6.2 \%\end{array}$ & $\begin{array}{c}21 \\
11 \%\end{array}$ & $\begin{array}{c}12 \\
6.2 \%\end{array}$ & $\begin{array}{c}56 \\
29 \%\end{array}$ & $\begin{array}{c}43 \\
22.2 \%\end{array}$ & $\begin{array}{c}32 \\
16.6 \%\end{array}$ & $\begin{array}{c}17 \\
8.8 \%\end{array}$ & $\begin{array}{c}193 \\
100 \%\end{array}$ \\
\hline
\end{tabular}

Table 4 Number of research papers presented by faculty at annual sessions at OUSL

It is evident from Table 4 that the Faculty of Natural Sciences topped the list in the stated period with 56 presentations, followed by the Faculty of Humanities and Social Sciences (43 presentations) and the Faculty of Education (32 presentations). The last in the list is the Faculty of Engineering Technology with 12 presentations on core engineering disciplines.

Table 5 indicates the biannual research journals published by the different faculties of the university. Although these are supposed to be published biannually, their printing is governed by the number of submissions by staff members.

\begin{tabular}{|l|l|l|}
\hline \multicolumn{1}{|c|}{ Name of journal } & \multicolumn{1}{|c|}{ Faculty } & \multicolumn{1}{c|}{$\begin{array}{c}\text { Number of issues published in the } \\
\text { last 5 years }\end{array}$} \\
\hline $\begin{array}{l}\text { 1. OUR-Engineering } \\
\text { Technology }\end{array}$ & $\begin{array}{l}\text { Faculty of Engineering } \\
\text { Technology }\end{array}$ & $\begin{array}{l}\text { Although this is a biannual journal, no } \\
\text { issues were published between 2005 } \\
\text { and 2011 due to a lack of articles. }\end{array}$ \\
\hline $\begin{array}{l}\text { 2. VISTAS - Journal } \\
\text { of Humanities, } \\
\text { Social Sciences } \\
\text { and Education }\end{array}$ & $\begin{array}{l}\text { Faculty of Humanities } \\
\text { and Social Sciences }\end{array}$ & $\begin{array}{l}\text { Biannual journal, several issues were } \\
\text { published between } 2005 \text { and } 2011 .\end{array}$ \\
\hline $\begin{array}{l}\text { 3. ADEEKSHA Journal } \\
\text { of Education }\end{array}$ & Faculty of Education & $\begin{array}{l}\text { Biannual journal, several issues were } \\
\text { published between 2005 and 2011. }\end{array}$ \\
\hline 4. OUSL Journal & Faculty of Education & $\begin{array}{l}\text { Biannual journal, several issues were } \\
\text { published between 2005 and 2011. }\end{array}$ \\
\hline
\end{tabular}

Table 5 The number of issues of journals published by OUSL's faculties

It can be seen that no issue of the OUR - Engineering Technology journal was published from 2005 to 2011 due to a lack of papers from the Faculty of Engineering Technology's staff members. This is another clear indication of the lack of research-based articles written by the Faculty of Engineering Technology's staff members. 
Contribution to research when engineering is taught through ODL:

A Sri Lankan case study

Table 6 provides a summary of conference papers and journal articles produced by OUSL staff members from the various faculties over the last five years. This data was extracted from the 2005 to 2009 OUSL Annual Reports.

\begin{tabular}{|l|l|c|c|c|c|c|c|}
\hline \multirow{3}{*}{ Faculty } & \multirow{2}{*}{ Type of Publication } & \multicolumn{5}{c|}{ Year } & \multirow{2}{*}{ Total } \\
\cline { 3 - 7 } & & $\mathbf{2 0 0 5}$ & $\mathbf{2 0 0 6}$ & $\mathbf{2 0 0 7}$ & $\mathbf{2 0 0 8}$ & $\mathbf{2 0 0 9}$ & \\
\hline \multirow{2}{*}{ Education } & International Conference & 09 & 11 & 06 & 06 & 05 & 37 \\
& Local Conference & 08 & 10 & 16 & 08 & 11 & 53 \\
& Journal Articles & 06 & 02 & 05 & 02 & 02 & 17 \\
\hline \multirow{2}{*}{ Engineering } & International Conference & 05 & 03 & 07 & 02 & 02 & 19 \\
& Local Conference & 08 & 06 & 10 & 17 & 18 & 59 \\
& Journal Articles & 03 & 02 & 05 & 07 & 06 & 23 \\
\hline \multirow{2}{*}{ HSS } & International Conference & 02 & 05 & 14 & 03 & 00 & 24 \\
& Local Conference & 07 & 28 & 17 & 26 & 26 & 104 \\
& Journal Articles & 05 & 07 & 03 & 03 & 09 & 27 \\
\hline \multirow{2}{*}{ Nat. Science } & International Conference & 08 & 03 & 06 & 12 & 06 & 35 \\
& Local Conference & 14 & 15 & 38 & 38 & 28 & 133 \\
& Journal Articles & 12 & 05 & 03 & 12 & 05 & 37 \\
\hline
\end{tabular}

Table 6 OUSL staff publications, 2005 to 2009

Source: OUSL Annual Reports, 2005 to 2009

\section{Methodology}

A questionnaire survey was conducted among the academic staff members of the Faculty of Engineering Technology in order to take a snapshot of their research profile in 2010. It was also done to get their views on the different aspects of research. At the time of the survey, the faculty had 54 permanent academic staff members (professors, senior lecturers and lecturers). The questionnaire was given to all 54 staff members and 44 of them responded. The return rate was $81.5 \%$.

The questionnaire had seven questions. The questions were on: the number of conference papers presented in 2010; the number of journal articles published in 2010; the year the last conference paper or journal article was published; research grants obtained in 2010; satisfaction with research performance in 2010; reasons for not being able to perform research; and reasons for the lack of publications in engineering and technology. 


\section{Analysis and results}

The following responses were obtained from the 44 respondents:

1. Conference presentations: A total of 26 papers were presented by the staff members in 2010 , out of which six were presented overseas and 20 locally.

2. Journal articles: The faculty members published nine journal articles in 2010, out of which five were in local journals and the remainder in international journals.

3. Last paper published either in conference proceedings or journals: The answers obtained are summarised in Table 7.

\begin{tabular}{|l|c|}
\hline \multicolumn{1}{|c|}{$\begin{array}{c}\text { The year of last publication or } \\
\text { presentation }\end{array}$} & $\begin{array}{c}\text { Number of staff } \\
\text { members }\end{array}$ \\
\hline 2010 & 12 \\
\hline 2009 & 09 \\
\hline 2008 & 02 \\
\hline 2007 & 04 \\
\hline 2006 & 01 \\
\hline 2005 & 01 \\
\hline 2000 to 2005 & 04 \\
\hline Before 2000 & 04 \\
\hline No presentations or publications & 09 \\
\hline
\end{tabular}

Table 7 Last conference presentation or publication

Out of the 44 respondents, nine (20.5\%) admitted that they had never published or presented a paper in any conference.

4. Research grants: Only one faculty member obtained a research grant in 2010.

5. Self-satisfaction: Forty respondents (91\%) were unhappy with the extent of research they conducted. 
6. Reasons for not being able to perform research at a reasonable level: Figure $\mathbf{1}$ shows the reasons cited by respondents for the poor research record. The main reasons given were lack of time for research due to the large number of students, lack of research culture and environment, and continuous assessment marking. No one cited poor health or lethargy as reasons.

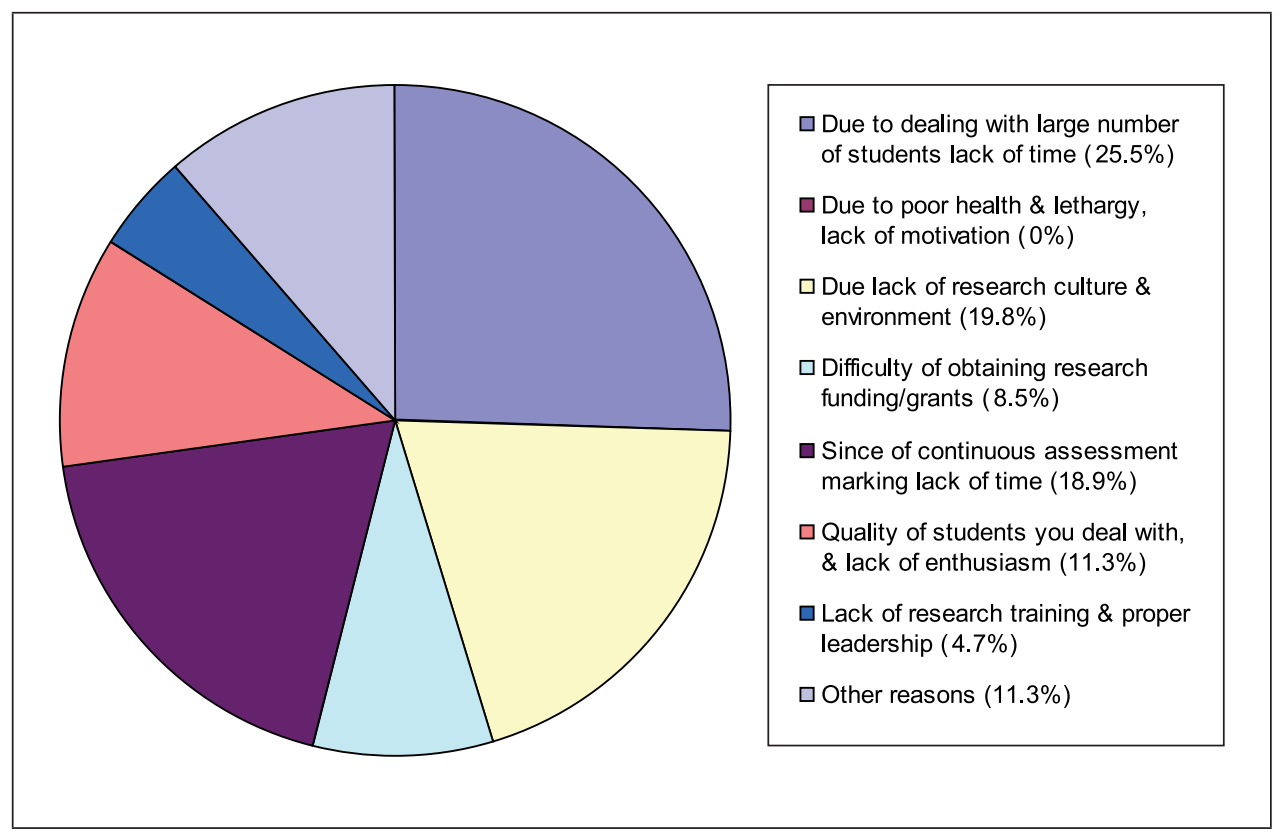

Figure 1 Reasons for not being able to perform research

7. Reasons for comparatively poor performance by Engineering Technology faculty staff members: Figure 2 shows the reasons given by respondents for the poor research record of the engineering faculty academics. Some $33.8 \%$ of the respondents said that conducting engineering-related research is more difficult. Another $33.8 \%$ said that they are more conscious about the quality of the papers rather the number of papers they produced. Another $27.9 \%$ believed that producing papers in some other disciplines is easier. 


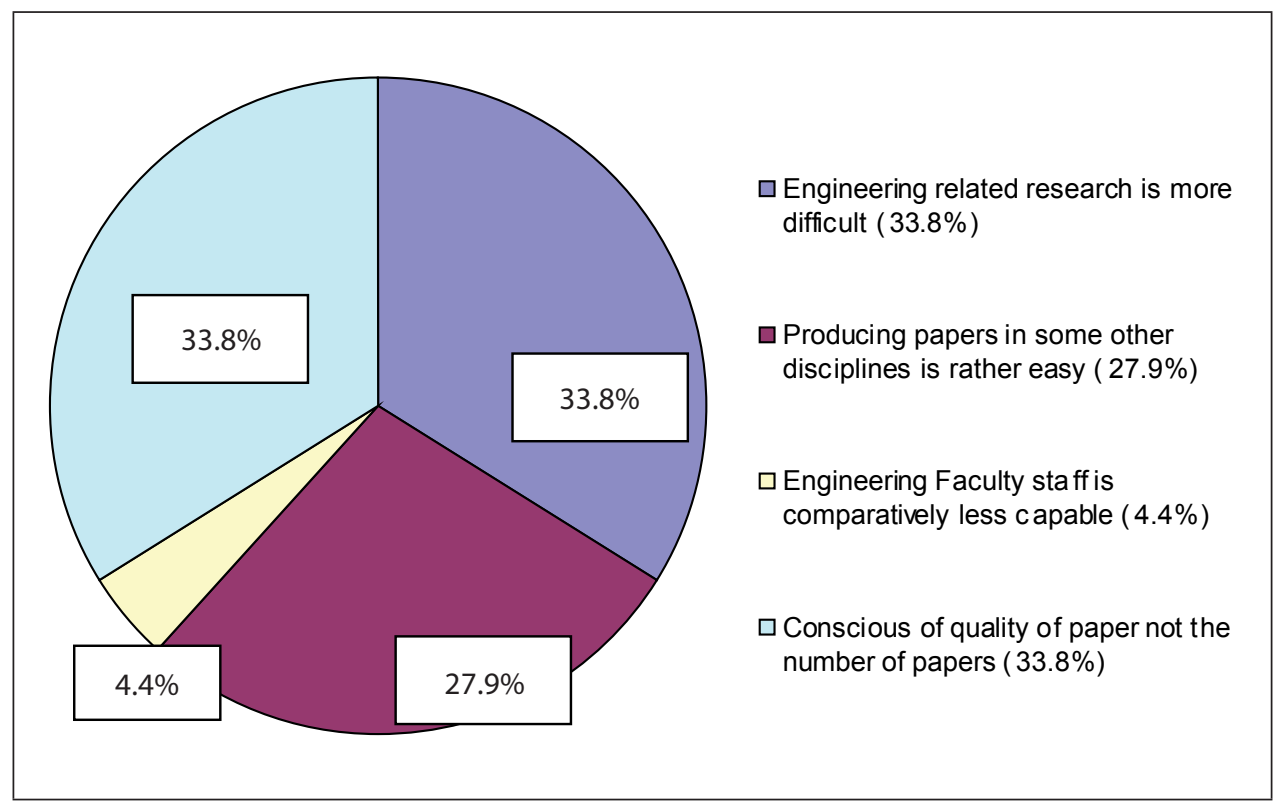

Figure 2 Reasons for the poor research performance of the Engineering Technology faculty staff members

\section{Conclusion}

This study revealed that the staff members of the Faculty of Engineering Technology presented fewer research papers at conferences and published fewer journal articles than the staff of the other faculties in the Open University of Sri Lanka. In terms of the number of publications, the Faculty of Natural Sciences topped the list, followed by the Faculty of Humanities and Social Sciences, the Faculty of Education, and lastly, the Faculty of Engineering Technology. The main reason for this low output of engineering-related research was the lack of time. Staff members were unable to devote more time to research due to the following factors: (i) handling of a large number of students, (ii) continuous assessment process, (iii) conducting pre-orientation and orientation programmes in marketing the courses, (iv) having to counsel a large number of students and registering them, and (v) activities in regional and study centres. The other reasons were a lack of research culture in the ODL environment and difficulty in conducting engineering research, which involves a considerable amount of input in field work, laboratory work, data analysis, calibration and validation processes. All these factors jointly contributed to the low level of research output from the Faculty of Engineering Technology at OUSL.

Kolita S. Weerasekera is in the Department of Civil Engineering, Open University of Sri Lanka, Nawala, Nugegoda, Sri Lanka.E-mail: kswee@ou.ac.lk 
Contribution to research when engineering is taught through ODL:

A Sri Lankan case study

\section{References}

Braimoh, D. (2002). Assuring quality through institutional collaboration on study materials development for distance learners. In Access \& Equity: Challenges for Open and Distance Learning (Ch. 5, pp 243-251). New Delhi: Republika Press Pvt. Ltd.

Gunawardena, C. and Ekanayake, M. B. (2010). A tracer study of graduates of The Open University of Sri Lanka 2009, The Open University of Sri Lanka.

Kulasooriya, S. A. (2011, February 13). Yes we can, Sri Lankans can be innovative and productive. The Sunday Times Plus, p. 8.

Lephoto, H. M. (2000). Democratising education for the professional development of change agents through distance education process: The case of Lesotho. Indian Journal of Open Learning, 9(2), 36-42.

National Science Foundation (2008). Sri Lanka Science, Technology \& Innovation Statistical Handbook 2008. Colombo: NSF.

Open University of Sri Lanka (2005, 2006, 2007, 2008 and 2009). Annual Reports, Sri Lanka: OUSL. 